\title{
Numerical Analysis of Precast Wall Panels with Openings
}

\author{
Saad Abdulqader Ali Joda ${ }^{1}$, Abdul Aziz Bin Abdul Samad ${ }^{1 *}$, Noridah \\ Mohamed $^{1}$
}

${ }^{1}$ Department of Civil and Environmental Engineering

Universiti Tun Hussein Onn, Batu Pahat, Johor, MALAYSIA

*Corresponding Author

DOI: https://doi.org/10.30880/ijscet.2020.11.02.004

Received 30 July 2020; Accepted 30 August 2020; Available online 02 September 2020

\begin{abstract}
A finite element (FE) analysis study on precast concrete solid and sandwich wall panels with various openings subjected to axial eccentric load $\left(\mathrm{t}_{\mathrm{w}} / 6\right)$ is presented in this paper. Experimental work of nine full-scale and six half-scale wall panels from selected studies were modelled using ABAQUS 6.13 software. The cracking pattern, plastic strain and ultimate load carrying capacity of these FE models were analyzed and comparison from the selected studies was conducted for verification. Results from the FE analysis revealed that the behavior of the wall panels was influenced by the size and location of the openings and its slenderness ratios. From the ultimate load carrying capacity of a solid wall panel and sandwich wall panels with openings, a difference of within $10 \%$ of the experimental work from the selected studies was recorded. This observation verifies that ABAQUS finite element software is a reliable and effective technique in determining and establishing the structural behavior of precast wall panels with openings.
\end{abstract}

Keywords: Precast Solid Wall Panels, Precast Sandwich Wall Panels, Openings, Numerical Simulation, ABAQUS

\section{Introduction}

Today, half of the world's 7.5 billion population resides in huge cities and it is estimated that $67 \%$ of the total population will be living in huge cities by the year 2050. This resulted in engineers developing innovative and quick construction techniques with sustainability to bring about a cost-effective solution instead of the traditional construction practices used currently (Yee \& Eng, 2001) (Yee, 2001). Precast wall panel (PWP) is one of the innovative techniques developed by the engineers working in this domain and this technology can be used to decrease the time of construction (Brzev \& Perez 2010).

PWP structures have been used more and more in the industrialised construction process and have become popular over the recent years (Losch, Hynes, Andrews Jr, Browning, Cardone, Devalapura, \& Kourajian, 2011). This structures are extensively used as load bearing components for tilt-up constructions, in the case of high-rise structures in general and urban regions in particular (Kukmar, \& Sai, 2018). There have been a few studies on the PWP structures with openings which established certain noteworthy conclusions (Guan, Cooper, \& Lee, 2010). The most basic reason of the falling of a wall is either by compressed portion crushing or tension portion bending. Additionally, a wall may also fall through buckling (Jaseela, \& Pillai, 2017). 
The present codes of (ACI318-2011, AS3600-2001 and EC2-2004) provisions are not provide adequate design procedures and unable to incorporate the equations on the load carrying capacity with openings in the wall and these procedures are also limited to wall having the slenderness ratio less than 32 (Lee, \& Oh, 2010).

Conversely, the earlier studies proved that if there are smaller openings with respect to the dimension of the wall, it is reasonable to ignore the impact of the opening. But, in certain cases where the opening is located in a crucial area, inelastic distortions can occur. In these cases, the effect of the opening on the behaviour of the wall must be taken into consideration (Taylor, Cote, \& Wallace, 1998).

Thus, the objective of the present paper is to carry out a statistical analysis of one-way action PWP structure with openings (with top and bottom support only) using the technique of finite element, compared to the earlier experimental studies conducted by (Saheb, \& Desayi, 1990), in case of solid wall as well as (Aziz, Ali, Jaafar, Samad, \& Trikha, 2004) in case of sandwiched wall panel with many different types of openings. Such openings decrease the structure's strength considerably and it leads to assessment of the effect of the configuration of openings on the strength.

The openings lead to weakness and, depending on the size, can decrease the stiffness and capacity of load bearing of the structure. Also, the wall openings significantly decrease the highest load capacity as compared to the solid wall of equivalent size. The area around the openings (windows and doors) has a high concentration of stresses (Mohammed, Bakar, \& Choong, 2009). At these regions, the effects of the openings are studied exhaustively.

\section{Previous experimental work}

(Saheb, \& Desayi, 1990) initiated the first experimental work producing sufficient quantity of experimental data on 6 half scale solid precast wall panel (PWP) with windows and doors openings as illustrated in Fig. 1. The PWP structure was exposed to a consistent axial eccentricity load of (tw/6) along with simple supports to estimate the panel strength. The outcomes from the experimental work demonstrated that panel with two window openings cracked at a load of $143.18 \mathrm{KN}$ (33\% of the highest possible load), and panel having a central window cracked at a load of 483.97 $\mathrm{KN}$ ( $72 \%$ of the highest possible load). Alternatively, the lateral deflection was shown to vary in a linear manner with load applied up to approximately $60 \%$ of the highest load.

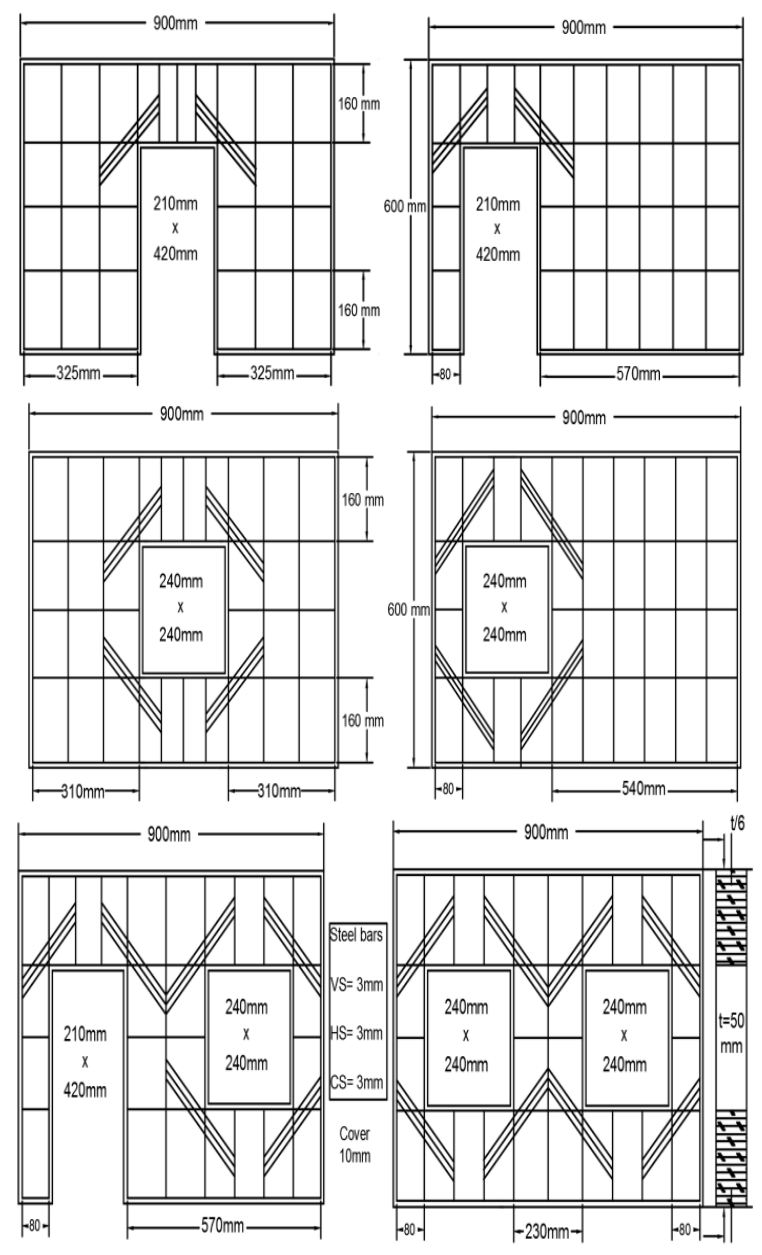

Fig. 1 - Solid precast wall panel with windows and doors openings 
Aziz, Ali, Jaafar, Samad, \& Trikha (2004) performed an experimental work on three sandwich PWP with openings subjected to axial load. The experiment assesses the behaviour of the panel for its damage, cracking and highest load bearing capacity. Fig. 2 shows the three sandwich PWP with window and door openings. The findings from the experimental work demonstrated that sandwich PWP with window and door opening recorded its first crack at $28 \%$ of its highest load capacity, whilst the panels with only door or window opening cracked at $54 \%$ and $30 \%$ of their ultimate load capacity respectively. Comparing all the results, the highest load bearing capacity of the specimen panels with windows and with doors openings reached up to $936.19 \mathrm{KN}$.
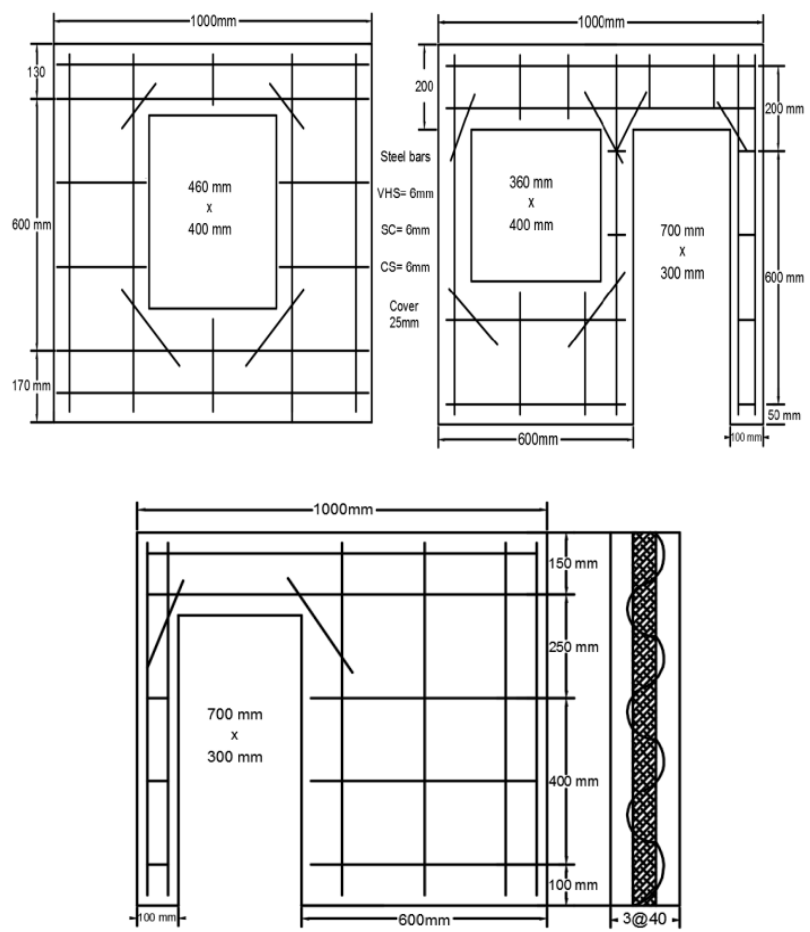

Fig. 2 - Sandwich precast wall panels with window and door openings

\section{Non-Linear Finite Element Simulation}

3D finite element software called ABAQUS (System, D. 2013). was adopted for the modelling of solid and sandwich precast wall panels with window and door openings. The choice of selecting this software was made by observing the comparative assessment study conducted by (Mohamed, Goh, Abdullah, Samad, Mendis, \& Sofi, 2017) and (Risan, Harba, \& Abdulridha, (2017), which shows good agreement between the experiment work and ABAQUS finite element simulation study.

ABAQUS/Explicit Dynamic 6.13 offers an effective way of assessing the non-linear elastic-plastic failure performance, with an attribute of Concrete Damage Plasticity in quasi-static loading so as to simulate the fragility performance depending on the connection between the stress-strain in the behavior under tension and compression. This portion describes the various entries and functions to be used to produce the FE calibration model. The efficacy and validity of numerical outcomes for the recommended concrete material and wall panel's performance will be verified with the experimental outcomes conducted by (Saheb, \& Desayi, 1990) and (Aziz, Ali, Jaafar, Samad, \& Trikha, 2004).

\subsection{Constitutive models for materials}

\subsubsection{Model geometry of panels}

In this study, the solid PWP and sandwich PWP were modeled using ABAQUS finite element software with the same dimensions to the previous experimental work done by (Saheb, \& Desayi, 1990) (Aziz, Ali, Jaafar, Samad, \& Trikha, 2004). Fig. 3 and Fig. 4 shows the prototype model of the solid and sandwich panels consisting of concrete, modeled as Continuum 3-Dimensional 8 node linear brick component, reduced integration and hourglass control (C3D8R) with 3 degrees of freedom in every node was used. Whereas the steel reinforcement and shear connectors were modeled using a 3-Dimensional 2-nodes truss component (T3D2). All the solid and sandwich wall panels were incrementally subjected to an axially eccentric load located at tw/6. 


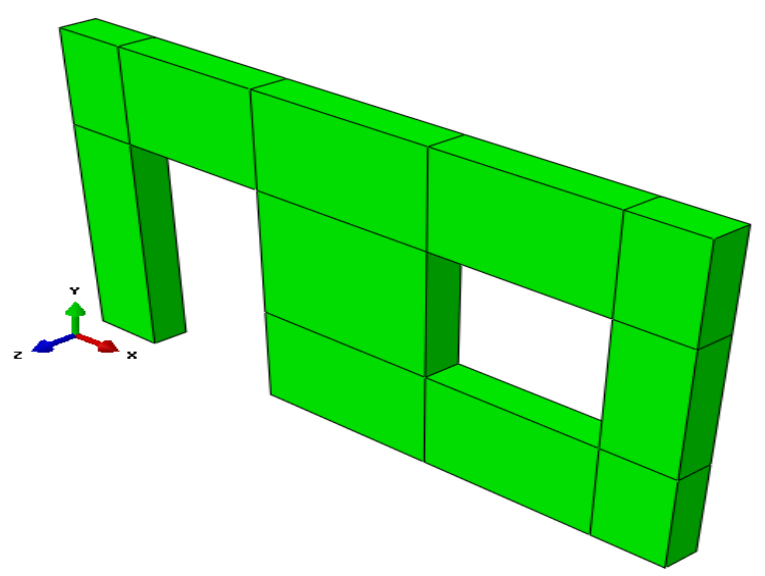

Fig. 3 - Configuration of PWP solid model with opening

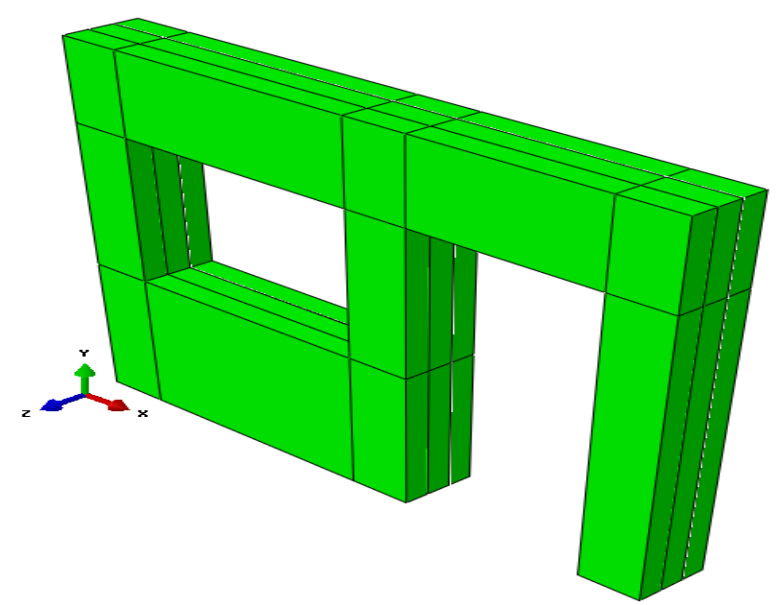

Fig. 4 - Configuration of PWP sandwich model with opening

\subsubsection{Concrete model}

Modeling the non-linear behavior of concrete based on plasticity theory is called the Concrete Damage Plasticity (CDP) (System, D. 2013), developed by (Lubliner, Oliver, Oller, \& Onate, 1989) and later modified by (Lee, \& Fenves, 1998). A typical concrete in compression and tension is shown in Fig. 5 and Fig. 6 respectively. The model assumes that the two main concrete failure mechanisms are compressive crushing and tensile cracking using the stiffness degradation and continuum damage mechanics. In both the compressive and tensile stress-strain curves, the unloading response was characterized by the weakening of the materials and scalar degradation of the elastic stiffness (Obaidat, 2011). These phenomena were identified by damage parameters.

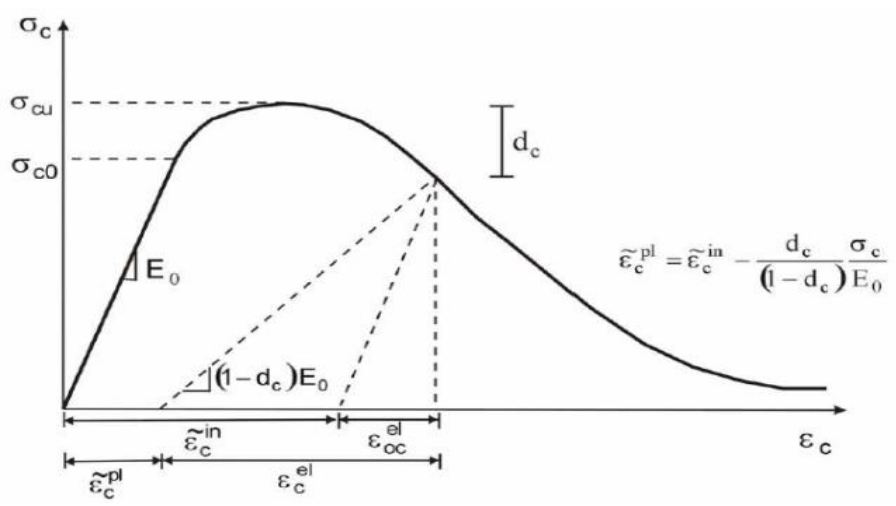

Fig. 5 - Plasticity based model response of concrete to uniaxial loading in compression 


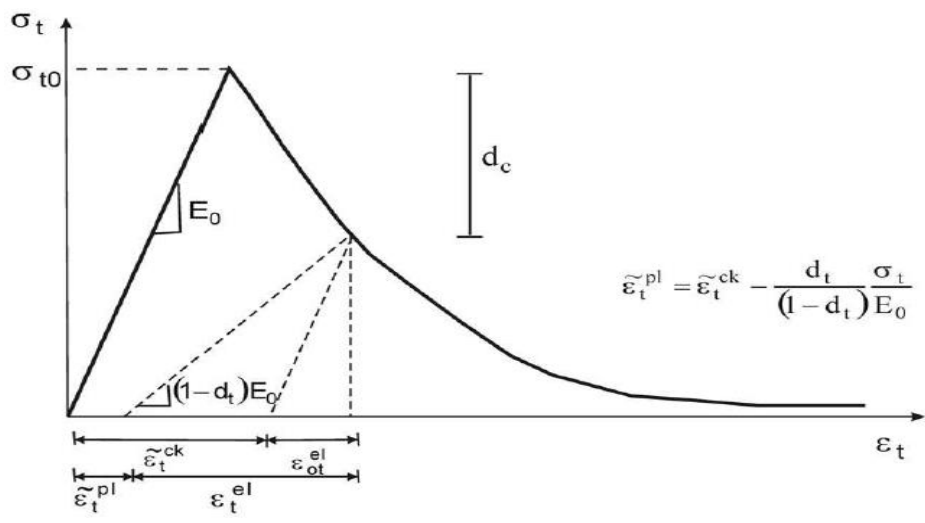

Fig. 6 - Plasticity based model response of concrete to uniaxial loading in tension

Table 1 shows the material properties of concrete in CDP model used in this study. These stress-strain parameters under compression and tension behaviour of the concrete were based on an equation taken from (Comite EuroInternational Du Beton 1990) and (Bridge, \& Wheeler, 2000).

Table 1 - Material properties of concrete in CDP

\begin{tabular}{|c|c|c|c|c|c|}
\hline \multicolumn{6}{|c|}{ Concrete damage plasticity } \\
\hline $\begin{array}{l}\text { Dilation } \\
\text { angle }\end{array}$ & $\begin{array}{c}\text { Eccentricity } \\
\text { e }\end{array}$ & $\begin{array}{r}\text { Initi } \\
\\
\sigma\end{array}$ & $\begin{array}{l}\text { iaxial } \\
\text { io } \\
\sigma \mathrm{b} 0\end{array}$ & $\mathrm{~K}$ & Viscosity \\
\hline $30^{\circ}$ & 0.1 & & & 0.667 & 0 \\
\hline \multicolumn{3}{|c|}{ Compressive behaviour } & \multicolumn{3}{|c|}{ Tensile behaviour } \\
\hline $\begin{array}{l}\text { Yield } \\
\text { Stress } \\
\text { (MPa) }\end{array}$ & $\begin{array}{l}\text { Inelastic } \\
\text { Strain }\end{array}$ & $\begin{array}{l}\text { Damage } \\
\text { Parameter }\end{array}$ & $\begin{array}{l}\text { Yield } \\
\text { Stress } \\
\text { (MPa) }\end{array}$ & $\begin{array}{l}\text { Cracking } \\
\text { Strain }\end{array}$ & $\begin{array}{c}\text { Damage } \\
\text { Parameter }\end{array}$ \\
\hline 15.244 & 0.000 & 0.000 & 1.887 & 0.000 & 0.000 \\
\hline 21.058 & 0.00038 & 0.000 & 0.783 & 0.015 & 0.594 \\
\hline 25.819 & 0.00088 & 0.000 & 0.310 & 0.065 & 0.842 \\
\hline 28.000 & 0.00158 & 0.000 & 0.171 & 0.133 & 0.916 \\
\hline 25.686 & 0.00238 & 0.082 & 0.000 & 0.270 & 1.000 \\
\hline 22.248 & 0.00288 & 0.205 & & & \\
\hline 14.000 & 0.00370 & 0.500 & & & \\
\hline 8.603 & 0.00438 & 0.692 & & & \\
\hline 5.018 & 0.00538 & 0.820 & & & \\
\hline
\end{tabular}

Damage $(d)$ parameters of concrete in compression $\left(d_{\mathrm{c}}\right)$ and tensile behavior $\left(d_{t}\right)$ in CDP model as represented in Table 1 and illustrated on Fig. 7 and Fig. 8 is expressed as follow:

$$
\mathrm{D}=1-\left(\mathrm{E} / \mathrm{E}_{0}\right)
$$

$\mathrm{D}: d_{\mathrm{c}}, d_{t}$ Damage variables in compression and tension

$\mathrm{E}$ : reduction of the elastic modulus

$\mathrm{E}_{0}$ : initial (undamaged) modulus of the material

Fig. 7a and Fig. 7b shows the inelastic failure of compression damage based on inelastic hardening strain under uniaxial loading, the concrete failed once reached the ultimate compressive strength with increasing of plastic strain due to the brittle behavior while the concrete started to sustain damage and the compressive strength decreased at post failure mode until it becomes totally damaged, furthermore, the damage parameter start increasing which influenced by the reduction of elastic modulus. 


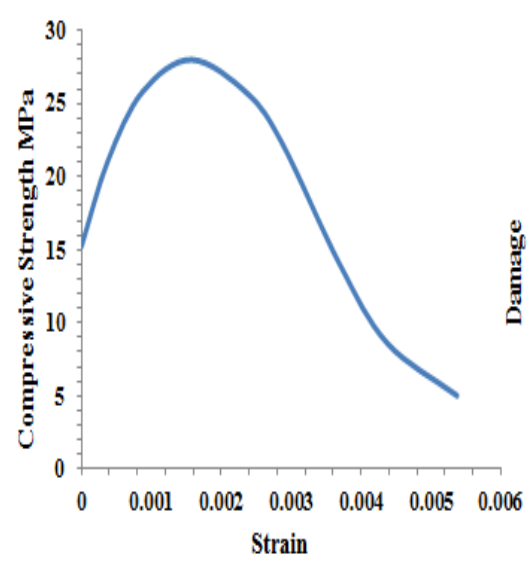

(a)

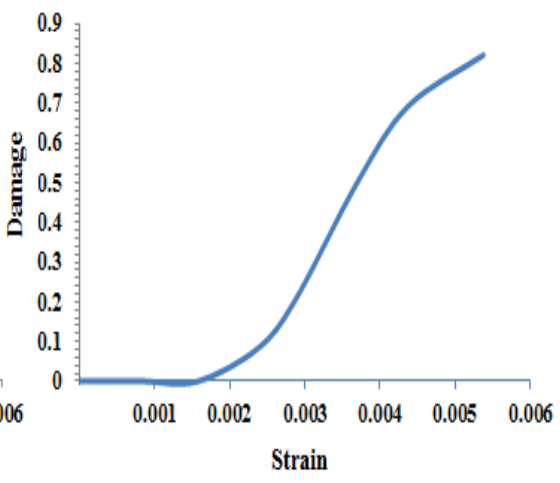

(b)

Fig. 7 - (a) Compression hardening-softening (b) Nonlinear compression strain softening of concrete

In tension damage when the concrete subjected to uniaxial tension loading during the splitting cylinder test as shown in Fig 8(a) and Fig. 8(b) shows that the tensile strength decreasing linearly until the ultimate tensile strength was reached and cracking is initiated. Beyond the failure stress the respond shows post-failure behavior for direct straining with tension stiffening, while the damage increasing gradually until failure.

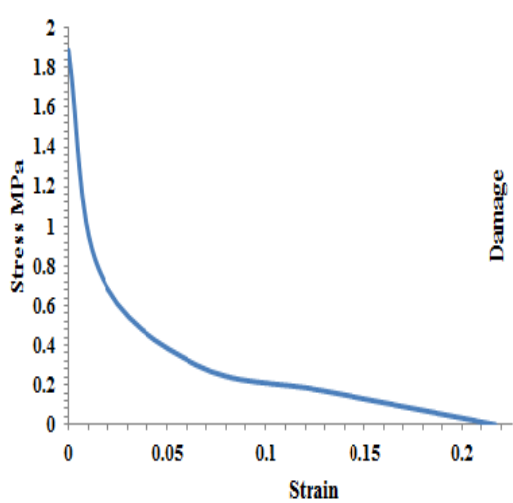

(a)

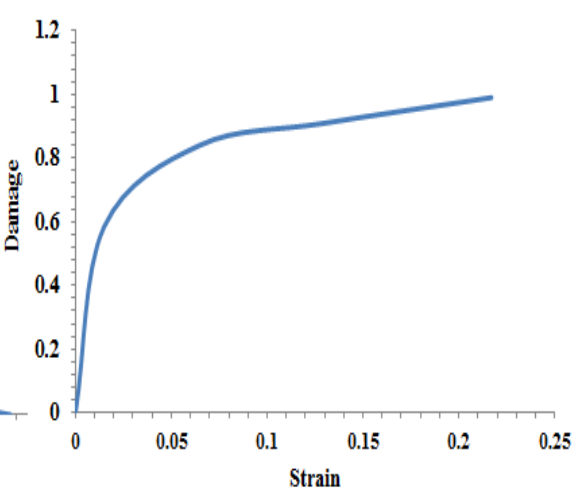

(b)

Fig. 8 - (a) Tension stiffening and (b) Tension damage of concrete

The other parameters of concrete plastic damage which included the flow potential eccentricity, the ratio of initial biaxial $\left(\sigma_{\mathrm{c} 0} / \sigma_{\mathrm{b} 0}\right)$, the ratio of the second stress invariant on the tensile meridian to that on the compression meridian (k) and the viscosity that defines the visco-plastic regularization were set recommended by (System, D. 2013), whereas, the value of dilation angle $(\psi)$ which characteristic the performance of concrete under compound stress was selected at $30^{\circ}$ to reach the best agreement with the experimental result and also was based on experimental studies have been done by (Lee, \& Fenves, 1998) and (Malm, 2009).

\subsubsection{Steel model}

The steel reinforcements and shear connectors are modelled as one-directional strain elements (rods) and are simulated by using rebar option and treated as classical metal elastic-perfectly plastic material with strain hardening in both compression and tension as shown in Fig. 9. The input values of steel reinforcement and shear connectors includes Poisson ratio and density and young Modulus were assumed as on regular properties of steel rod, while the other properties of yield stress, strain at failure and ultimate stress were obtained from previous experimental as shown in Table 2. After assembled with the PWP, embedded technique was used to constrain the main reinforcement and shear connectors into the solid element (concrete wall) in order to assume a perfect bond action between steel and concrete as shown in Fig. 9, Fig. 10 and Fig.11. 
Table 2 - Steel properties

\begin{tabular}{cccccc}
$\begin{array}{c}\text { Bar } \\
\text { diameter }\end{array}$ & $\begin{array}{c}\rho \\
\left(\mathrm{kg} / \mathrm{m}^{3}\right)\end{array}$ & $v$ & $\begin{array}{c}\mathrm{E}_{\mathrm{s}} \\
(\mathrm{MPa})\end{array}$ & $\varepsilon$ & $\begin{array}{c}f y \\
(\mathrm{MPa})\end{array}$ \\
\hline $2 \mathrm{~mm}$ & 7.700 & 0.3 & $2.05 \times 10^{5}$ & 0.0028 & 297 \\
$3 \mathrm{~mm}$ & 7.800 & 0.3 & $2.1 \times 10^{5}$ & 0.0067 & 985 \\
$6 \mathrm{~mm}$ & 8 & 0.3 & $2.0 \times 10^{5}$ & 0.0062 & 572.9 \\
$9 \mathrm{~mm}$ & 8 & 0.3 & $2.0 \times 10^{5}$ & 0.0089 & 546.8 \\
\hline
\end{tabular}

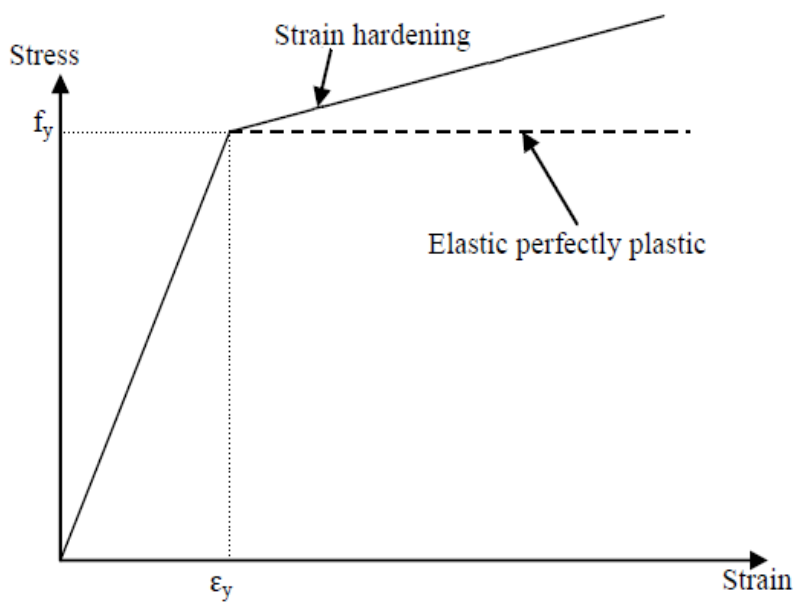

Fig. 9 - Idealized stress-strain curve for shear connectors and steel reinforcements

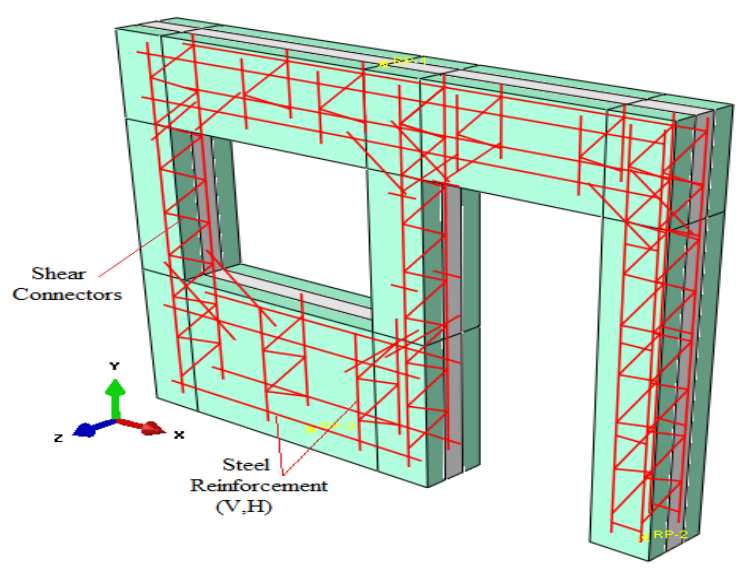

Fig. 10 - Embedded techniques of sandwich PWP elements

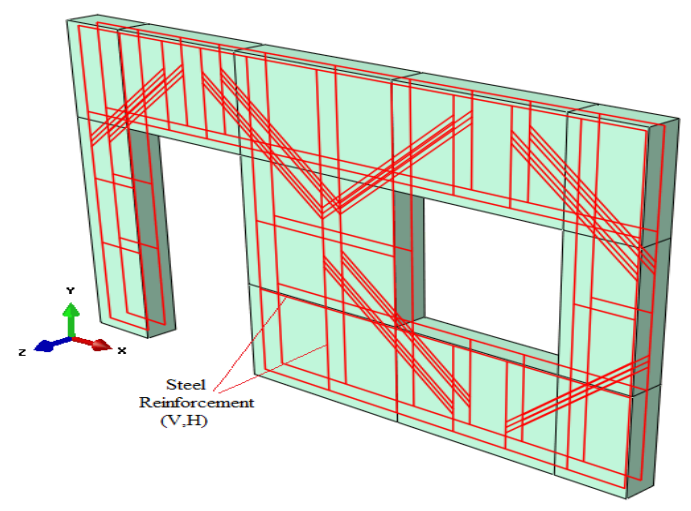

Fig. 11 - Embedded techniques of solid PWP elements 


\subsection{Mesh generation}

Mesh convergences studies of all panels were carried out by using displacement measurements. The sandwich PWP was meshed with an approximate element size of $10 \mathrm{~mm}$ while the solid PWP were meshed with an element size of $5 \mathrm{~mm}$ in transverse, longitudinal and thickness direction respectively. Table 3 shows the results of finer mesh giving the most reliable output compared to the experimental load-deflection curve, but admittedly much computational time was needed.

Table 3 - Results of mesh refinement study of PWP

\begin{tabular}{|c|c|c|c|c|}
\hline \multirow{2}{*}{$\begin{array}{l}\text { Mesh } \\
\text { size }\end{array}$} & \multirow{2}{*}{$\begin{array}{l}\text { Number } \\
\text { of } \\
\text { Elements }\end{array}$} & \multicolumn{2}{|c|}{$\begin{array}{l}\text { Ultimate Load } \\
\qquad \mathrm{P}_{\mathrm{u}}(\mathrm{KN}) \\
\end{array}$} & \multirow{2}{*}{$\begin{array}{l}\text { Percentage } \\
\text { differences } \\
\quad(\%)\end{array}$} \\
\hline & & FEA & Exp & \\
\hline GB 50 & 1172 & 543.61 & & 8.33 \\
\hline GB 35 & 2122 & 534.06 & & 6.70 \\
\hline GB 30 & 2552 & 531.13 & & 6.18 \\
\hline GB 25 & 4764 & 528.25 & 498.3 & 5.67 \\
\hline GB 20 & 6982 & 523.17 & & 4.75 \\
\hline GB 10 & 68076 & 507.45 & & 1.80 \\
\hline GB 5 & 529354 & 499.85 & & 0.31 \\
\hline GB 3 & 678358 & 497.05 & & -0.25 \\
\hline
\end{tabular}

\subsection{Boundary condition and loading}

The boundary conditions was a simply supported same with experimental studies, at the top side of the wall panels was simulated by using a technique of tie rigid body with the top surface and reference point, and then assigned a displacement the $\mathrm{Y}$ direction on the reference point to achieved the vertical loading and constrained at $\mathrm{X}$ and $\mathrm{Z}$ direction, at the bottom end a same technique were used on the reference point with constrained for no movement in $X$, $\mathrm{Y}$ and $\mathrm{Z}$ direction as depicted in Fig. 12 a vertical displacement was increased gradually to failure until reaching its ultimate load.

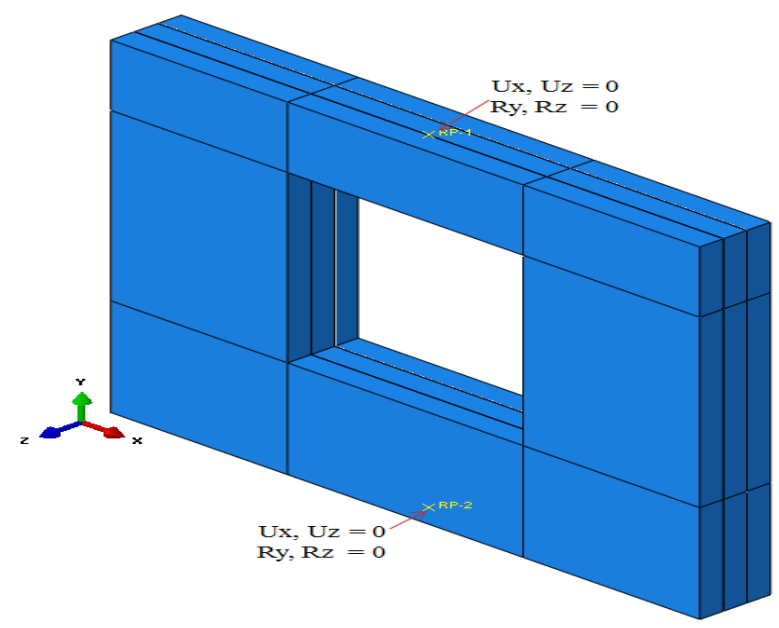

Fig. 12 - Loading and support condition of PWP

\subsection{Result and discussion}

Table 4 shows the identity of the six panels (three solid and three sandwich panels) modelled in ABAQUS. Comparing to (Saheb, \& Desayi, 1990) the resulting failure mechanisms with varying window and door openings shows good agreement from those at experimental work. However, it is generally known that CDP do not have the notion of cracks development and according to (Lubliner, Oliver, Oller, \& Onate, 1989) different criteria can be adopted which assume that cracking initiates at a point where the tensile equivalent strain is greater than zero and the maximum principle plastic strain is positive. The direction of the vector normal to the crack plane is assumed to be 
parallel to the direction of the maximum principle plastic strain, the test exhibited cracks propagating from the corners of openings to the corners of the panel as shown in Figs 13, 14, 15 and 16. By comparing with the experimental results, the FE model with two windows (WW/C) cracks at a load of $151.63 \mathrm{KN}$ which was $31.6 \%$ of the ultimate load. On the other hand, the FE model with window center (W/C) showed the highest cracking load at $550 \mathrm{KN}$ (77\% of the ultimate load).

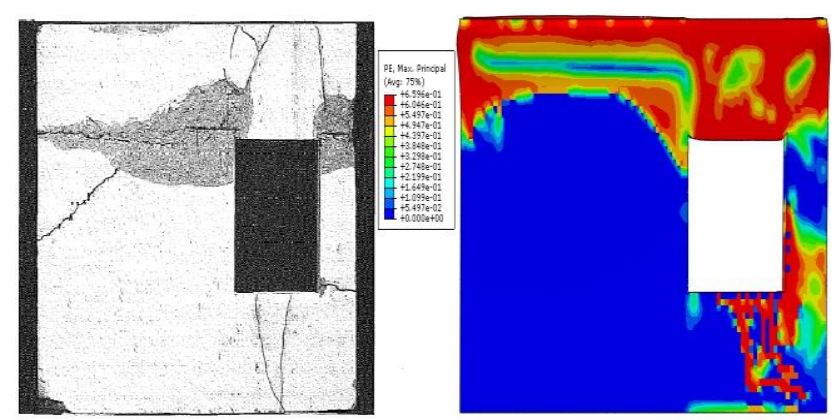

Fig. 13- Crack pattern of WE panel

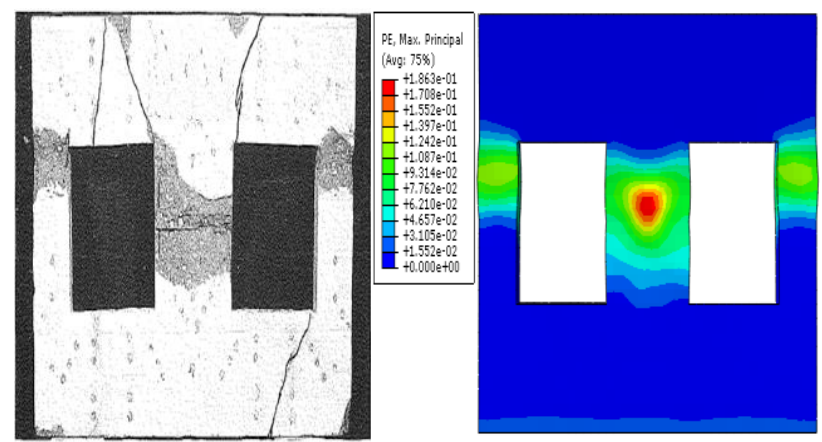

Fig. 14- Crack pattern of WW/C panel
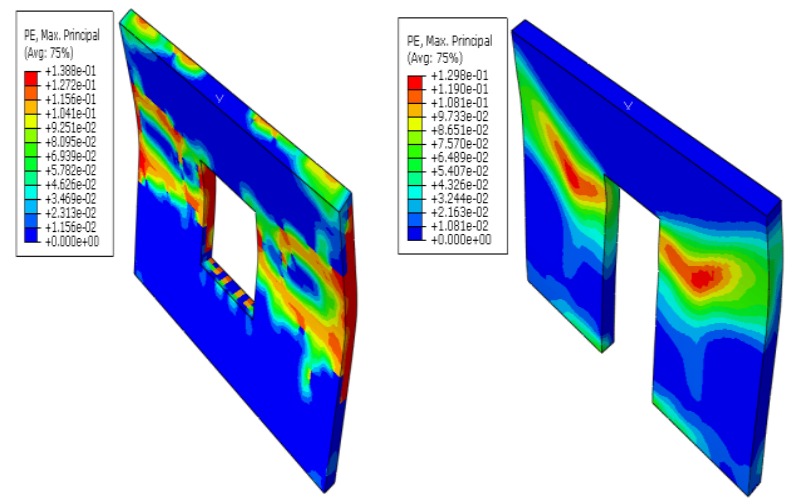

Fig. 15- Crack pattern of W/C and D/E panel

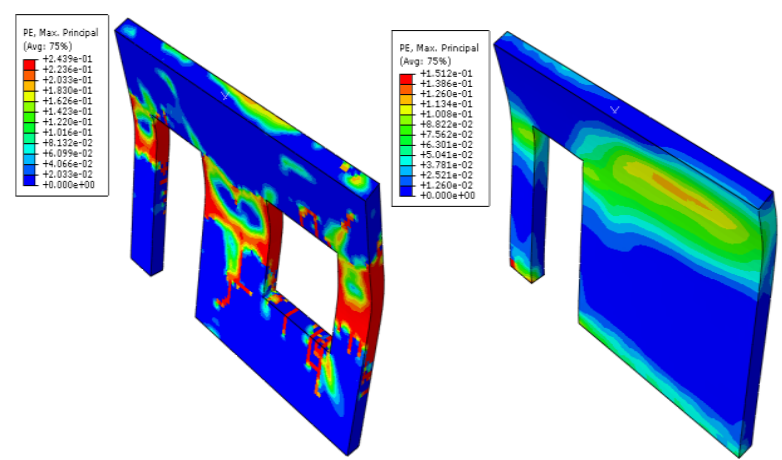

Fig. 16 - Crack Pattern of DW/E, D/E Panel 
The FEM ultimate load predictions are satisfactory but slightly overestimated as shown in Table 4, with comparisons to the experimental failure modes. The ratios of FEM to experimental vary from 0.913 to 1.014 . The discrepancies are due to the fact that the FEM model is idealistic, as the geometry, material and boundary conditions are assumed to be exactly as specified.

Table 4- Comparison of the ultimate axial load of solid pan
\begin{tabular}{cccc}
\hline Panel & $\mathrm{P}_{\mathrm{u} 0}^{\mathrm{e}}(\mathrm{EXP})$ & $\mathrm{P}_{\mathrm{u}}(\mathrm{FEM})$ & $\mathrm{P}^{\mathrm{e}}{ }_{\mathrm{uo}} / \mathrm{P}^{\mathrm{f}}{ }_{\mathrm{u}}$ \\
opening & $\mathrm{kN}$ & $\mathrm{kN}$ & 0.968 \\
\hline $\mathrm{W} / \mathrm{C}$ & 672.56 & 694.35 & 0.913 \\
$\mathrm{D} / \mathrm{C}$ & 652.65 & 714.17 & 0.988 \\
$\mathrm{~W} / \mathrm{E}$ & 568.90 & 575.75 & 0.899 \\
$\mathrm{D} / \mathrm{E}$ & 548.02 & 609.21 & 1.014 \\
$\mathrm{WW} / \mathrm{C}$ & 433.47 & 427.47 & 0.983 \\
$\mathrm{DW} / \mathrm{E}$ & 423.47 & 430.48 & $\mathrm{C}$ \\
\hline
\end{tabular}

Note: $\mathrm{W}=$ window, $\mathrm{D}=$ door, $\mathrm{E}=$ edge and $\mathrm{C}=$ center

Comparing to (Aziz, Ali, Jaafar, Samad, \& Trikha, 2004) the FE analysis results are shown in Fig. 17 and Fig. 18. Failure modes of sandwich wall panels with shear connectors under axial compression compared to experimental result, shows that the behavior obtained from FEA of sandwich precast wall panel with door and window and with door at the edge; had crushing occurred at top and bottom of column and at the edge of window due the concentrate stresses at the critical zone with initial cracking load $59.37 \mathrm{KN}$ and $170.5 \mathrm{KN}$ respectively.

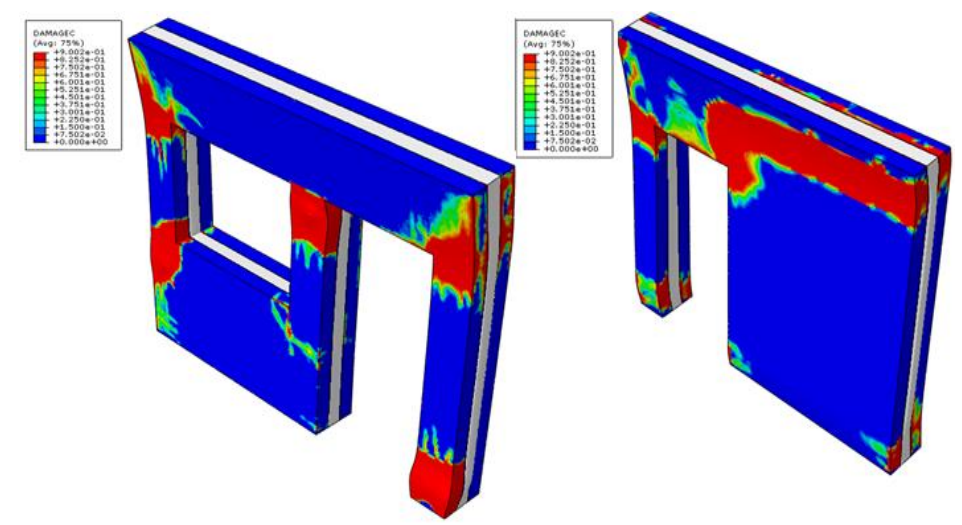

Fig. 17- Failure mode of panels with door and window edge and door at the edge

while the initial cracking load for panel with window at the center recorded at $168.31 \mathrm{KN}$ which represent the highest ultimate load as shown in Table 5.
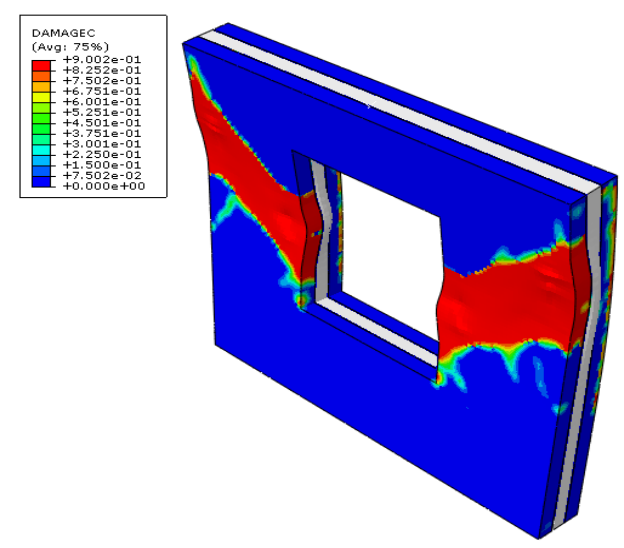

Fig. 18- Failure mode of panels with window at center 
Table 5 - Comparison of the ultimate axial load carrying of solid panels with shear connector.

\begin{tabular}{cccc}
$\begin{array}{c}\text { Panel } \\
\text { opening }\end{array}$ & $\begin{array}{c}\mathrm{P}_{\mathrm{u} 0}(\mathrm{EXP}) \\
\mathrm{kN}\end{array}$ & $\begin{array}{c}\mathrm{P}_{\mathrm{u}}(\mathrm{FEM}) \\
\mathrm{kN}\end{array}$ & $\mathrm{P}^{\mathrm{e}}{ }_{\mathrm{uo}} / \mathrm{P}_{\mathrm{u}}^{\mathrm{f}}$ \\
\hline $\mathrm{W} / \mathrm{C}$ & 906.2 & 872.77 & 1.038 \\
$\mathrm{D} / \mathrm{E}$ & 860.7 & 847.98 & 1.015 \\
$\mathrm{DW} / \mathrm{E}$ & 498.3 & 480.69 & 1.036 \\
\hline \multicolumn{4}{l}{ Note: $\mathrm{W}=$ window, $\mathrm{D}=$ door, $\mathrm{E}=$ edge and $\mathrm{C}=$ center }
\end{tabular}

\section{Conclusions}

A finite elements model was used to investigate the behavior of precast concrete wall panels by using ABAQUS 6.13, the results from finite elements were compared with experimental studies by (Saheb, \& Desayi, 1990) and (Aziz, Ali, Jaafar, Samad, \& Trikha, 2004), numerical predictions of cracking pattern, and ultimate load are in proximity to the experimental observations, it should be noted that the numerically predicted crack pattern indicate the crack directions only (not the crack width and length). This observation ensures that the ABAQUS finite element method software along with the concrete damage plasticity is capable of predicting the structural behavior of precast wall panels with openings. Numerical results also show that the openings and using core layer at the precast wall has a significant influence on the ultimate load carrying capacity.

\section{Acknowledgement}

The authors would like to acknowledge the Fundamental Research Grant Scheme (FRGS) Vot No. 1573 received from the Ministry of Higher Education Malaysia. The cooperation received from the Faculty of Civil and Environmental Engineering, Universiti Tun Hussein Onn Malaysia and School of Housing, Building and Planning, Universiti Sains Malaysia is highly appreciated.

\section{References}

ACI Committee 318 (2011). Building code requirements for reinforced concrete . American Concrete Institute Detroit

Aziz, F. N. A. A., Ali, A. A. A., Jaafar, M.S., Samad, A. A. A., \& Trikha, D. N. (2004). Ultimate strength of precast concrete sandwich panel with opening under axial load, MAJLIS BAGI SESI 2004/2005 (IEM COUNCIL SESSION), 8

Bridge, R. Q. \& Wheeler, A. T., (2000). Thin-walled steel tubes filled with high strength concrete in building. Composite Construction in Steel and Concerete IV: 584-595

EN, B. (2004). 1-1. Eurocode 2: Design of concrete structures-Part 1-1: General reules and rules for buildings. European Committee for Standardization (CEN)

Brzev, S., \& Perez T, G. (2010), Precast concrete construction. British Columbia Institute of Technology, pp. 1-11

Comite Euro-International Du Beton (1990) Design Code.Thomas Telford: CEP-FIP Model Code

Guan, H., Cooper, C., \& Lee, D. J. (2010). Ultimate strength analysis of normal and high strength concrete wall panels with varying opening configurations. Engineering Structures, 32(5), 1341-1355

Jaseela, C.A. \& Pillai, P.R.S. (2017) Concrete structural wall with cut-out openings: A parametric study. International Journal of Scientific \& Engineering Research, 8, 143-148

Kukmar, R. U. \& Sai, P. (2018). Analysis and design of precast load bearing wall for multi-storey building. International Journal of Innovative Research In Technology. 4, 341-350

Lee, D. J., \& Oh, S. T. (2010). Design equation of reinforced concrete walls for opening configurations. Journal of the Korea institute for structure maintenance and inspection, 14(3), 131-137 
Lee, J., \& Fenves, G. L. (1998) Plastic-damage model for cyclic loading of concrete structure. Journal of Engineering Mechanics, 124(8), 892-900

Losch, E.D., Hynes, P. W., Andrews Jr, R., Browning, R., Cardone, P., Devalapura, R., \& Kourajian, P. (2011), State of the art of precast/prestressed concrete sandwich wall panel. PCI Journal, 56(2), pp. 131-176

Lubliner, J., Oliver, J., Oller, S., \& Onate, E. A. (1989). A plastic-damage model for concrete. International Journal of Solids and Structures, 25(3), 299-326

Malm, R. (2009). Predicting shear type crack initiation and growth in concrete with non-linear finite element method. $\mathrm{PhD}$ Thesis, Royal Institute of Technology (KTH)

Mohammed, B.S., Bakar, B.H. A., \& Choong, K.K. (2009). The effects of opening on the structural behavior of masonary wall subjected to compressive loading-strain variation. Open Civil Engineering Journal, 3, 62-73

Mohamed, N., Goh, W. I., Abdullah, R., Samad, A.A.A., Mendis, P., \& Sofi, M. (2017). Structural performance of FCS wall subjected to axial load. Construction and Building Materials, Volume 134, 185-198

Obaidat, Y. (2011). Structural retrofitting of concrete beams using FRP-debonding issues. PhD Thesis, Lund University, pp22-36

Risan, H.K., Harba, I.S., \& Abdulridha, A.J. (2017). Numerical analysis of RC wall with opening strengthened by CFRP subjected to eccentric loads, Gradevinar, 69, 573-580

Saheb, S.M., \& Desayi, P. (1990), Ultimate strength of RC wall panel with openings. Journal of structural engineering (ASCE), 116(6), 1565-1577

Standard, A. (2001). Concrete structure, AS-3600. Sydney: Standards Association International

System, D. (2013). Abaqus . Online documentation. Abaqus User Subroutines Reference Manual

Taylor, C.P, Cote, P.A., \& Wallace, J.W. (1998). Design of slender reinforced concrete walls with openings. Structural Journal, 95(4), 420-433

Yee, A. A., \& Eng, P. H.D. (2001). Social and environmental benefits of precast concrete technology. PCI Journal, 46(3), 14-19

Yee, A. A. (2001). Structural and economic benefits of precast/prestressed concrete constructions. PCI Journal, 46(4), 34-42 